\title{
A COMPARATIVE STUDY OF KSHARSUTRA LIGATION AND ELECTRO-THERMAL CAUTERY IN THE MANAGEMENT OF ARSHA W. S. R. TO SENTINEL PILES
}

\section{Research article}

\author{
Anant kumar V Shekokar ${ }^{1^{*}}$, Kanchan M Borkar², Pradeep Badakh ${ }^{3}$ \\ 1. Reader and HOD, 2.Lecturer, 3.PG Scholar, \\ Dept.of Shalya-Tantra, S.V.N.H. Ayurved College, Rahuri.
}

\begin{abstract}
The disease Fissure with Sentinel Piles, an Ano-rectal disorder is as old as mankind. Still a large population of the world population is troubled with Fissure with Sentinel Piles which is perhaps due to inconsistency of the human diet and social obligations demanded by civilization .This disease is not generally threat to human life, but causes considerable discomfort, enforced bed rest, absence of mind from work with consequent economic strain, while the long range effects of this disease are induced weakness, which finally saps energy and enthusiasm of the patients.Ano-rectal disorder is progressively increasing in the society. Few important causes out of which number of them is sedentary life style, irregular diet and physiological disturbances like anxiety and depression.

The present study has been carried out to study the clinical efficacy of ksharsutra and Electro-Thermal cauterization in the management of sentinel pile was aimed. The clinical study was conducted on 60 patients selected randomly and divided into 2 groups based on the procedures for the clinical trial. First group was treated with Ksharsutra ligation. Second group was treated with Electro-Thermal cauterization. The clinical assessment was done on the basis of grading criteria with specific symptology of sentinel pile like Gudapida, Gudadaha, Rakta Srava, Sparshasahatwa, Guda Kandu, Shotha, GudaStrav, Malavasthmbha, Mansanankur. Then mean scores levels of these symptoms before and after the treatment of 2 groups where subject for student ' $t$ ' test for statistical analysis. The results were statistically and clinically significant not only to cure but also to prevent recurrence of the sentile piles.
\end{abstract}

Keywords: Kshara Sutra, Cautery, Arshas, Ligation method

\section{Introduction}

The fast food culture again worsens the condition as these foods are devoid of fibers(1) and hence causes more and more constipation. Because of constipation most

\footnotetext{
*Corresponding Author:

Anant Kumar Shekokar, Department of Shalya Tantra, S.V.N.H.Ayurved college, Rahuri.413706 Maharashtra, India Email:dranantkumarshekokar@gmail.com Ph.No: +91 9860376534
}

of Ano-rectal disorder occurs, Fissure with Sentinel Piles is one of them(2). Each and every human being desire to live happy and comfortable life, but it is not possible owing to multiple factors related with changing life style, environmental factors etc.

As per data available most of the population in the modern industrial society experience Anorectal disorders during their life. Fortunately in some of these it subsides within a time-bond, but in as many as of these recurs. 
Sentinel Piles has not been described in the Ayurvedic literature as a separate disease entity. It is true that this is probably the most painful condition(3) of this area but it is surprising to note how this condition escaped the attention of the ancient scientists. On the basis of symptoms, the disease fissure-in-ano can be compared to the disease Parikartika according to Ayurveda(4). Acharya Dalhana has described the term Parikartika as a condition of Guda in which there is cutting and tearing pain. Similarly Jejjata and Todara have clearly described Parikartika as a condition which causes cutting pain in ano-rectum. The factors responsible for causation of Parikartika as found in various texts are Vamana-Virechana-Vyapada, Bastikarma Vyapada, Atisara, Grahani, Arsha, Udavarta etc. In the similar manner Parikartika has been described of three types viz. Vattaja, Pittaja and Kaphaja(5). According to description of Acharya Charaka, it can say that Kshat Guda and Vikartika is the synonyms of Parikartika(6).

This diseases is particularly Vatic in nature. Burning however, is also associated which suggests that the Paittika involvement is also not very rare. But the presence of Kaphaja symptoms are very rarely seen in these cases suggesting the minimal Kapha vitiation. However, this may only be the academic or the scientific aspect of it. Therefore, any therapy which alleviates Vata and Pitta Dosha will be relieve any type of Parikartika.

Sentinel Piles is a sequel of chronic fissure in ano(7). In Ayurvedic text no specific description available as a sequel of Parikartika but lots of references available with help of that we can compare Sentinel Piles with Ayurvedic pathogenesis. In Ayurvedic text information available on Shushkarsh, Bahyarsh, Vataj, Janmottar-kalaj Arsha can be correlated with Sentinel Piles.
Acharya Sushruta has mentioned four modalities of management(8),
a) Bheshaja
b) Kshara
c) Agni d)

Shastra.

This approach seems to be graded on the basis of symptoms. He was master in the field of surgery, he was always employing safe, simpler \& non-invasive parameters for the management of Arsha.

The present trend in the treatment of Sentinel Piles is conservative lines, which include oral analgesics, antibiotics, antacids, stool softners, local anaesthetics. Stool softener may be used to make the stool soft, weak bulk laxative or cathartics are the best. Soothing ointment, self dilatation etc. are considered to be of sufficient usefulness. Where as injection of long acting anaesthetic solution though promotes relief but not free from complications(9).

In modern surgical practices, for the surgical management of Sentinel Piles, Lord's anal dilatation, lateral sphincterotomy and Excision of the anal ulcer along with skin graft and Excision of Sentinel Piles by Electro-Thermal Cautery are used. But all these techniques have limitations \& not free from post operative complications \& recurrences(10), Hence it leaves a scope to find out remedial modalities which would ideally offered cure of the disease in a shorter time, free from complications, no recurrence \& economically cheap.

In modern surgical technic, Electro-Thermal Cautery is routinely used for Sentinel Piles while in Ayurveda, Kshar-Sutra Ligation is routinely used.

Hence the present work has been planned, to compare Ksharsutra Ligation and Electro-Thermal Cautery in the management of Arsha with Special Reference To Sentinel Piles.

\section{Aims \& Objectives}

1. To study the etiological factors of Arsha in the influence of Ayurvedic and Modern parameters. 
2. To study the efficacy of Ksharasutra Ligation in themanagement of Arsha with w.s.r. to Sentinel Piles.

3. To study the efficacy of ElectroThermal Cautery in the management of Arsha w.s.r. to Sentinel Piles.

\section{Drug Review}

\section{Prepration}

Drugs Required For Ksharasutra
1. Haridra
2. Apamarg Kshara
3. Snuhi Ksheera
4. Linen Thread No.20

\section{Method of Preparation(11)}

At first the thread is spreaded, longitudinally on the hangers, specially designed for this purpose. The Snuhi latex is now, applied over the threads on its whole length with the help of gauze piece, hands should be gloved before smearing. The wet threaded hangers should be placed inside Kshara Sutra cabinet. It is dried for a day, the next day, dried thread again smeared with Snuhi latex.

This process is repeated for 7 days, on the $12^{\text {th }}$ day the thread is again smeared over the Apamarga Kshara powder. The thread is now allowed to dry and the same procedure is repeated for 7 more days. At $19^{\text {th }}$ day, the dried thread is smeared again with Snuhi latex and weighed Haridra powder is spreaded over the thread, the process is repeated for 3 consecutive days.

After 21 coatings are completed, each thread measuring about 10 to 11 inches should be cut away from the hangers and sealed in glass tubes.

\section{Total Days of Coating}

- Snuhi Ksheera - 11

- Apamarga Kshara - 7

- Haridra - 3
Table 1.1.Analytical Report Of Ksharsutra Thesis Drug

(It was done in S.V.N.H.T's Ayurved College, Research Department)

\begin{tabular}{|l|l|l|}
\hline $\begin{array}{l}\text { Sr. } \\
\text { No. }\end{array}$ & Name of the test & $\begin{array}{l}\text { Kshar- } \\
\text { Sutra }\end{array}$ \\
\hline $\mathbf{1}$ & Total weight & $890 \mathrm{mg}$ \\
\hline $\mathbf{2}$ & $\begin{array}{l}\text { Weight of coated } \\
\text { material }\end{array}$ & $82 \mathrm{mg}$ \\
\hline $\mathbf{3}$ & Length & $35.6 \mathrm{~cm}$ \\
\hline $\mathbf{4}$ & Diameter & $2.92 \mathrm{~mm}$ \\
\hline $\mathbf{5}$ & pH & 10.25 \\
\hline $\mathbf{6}$ & Moisture content & $2.31 \%$ \\
\hline $\mathbf{7}$ & Total ash content & $79.38 \%$ \\
\hline
\end{tabular}

\section{Ayurvedic Aspect of Cauterisation}

The para-surgical procedure like Agnikarma has widely been advised by Sushruta in case of Sira, Snayu, Asthi, Sandhigata disorders \& claimed to be highly effective where as Agnikarma treatment has provided marked relief $\&$ no recurrence.

While practicing Agnikarma, it is very important to create proper Samyak Vrana, so that desirable results are obtained.

\section{Samyak Dagdh Lakshana(12)}

Sushrutacharya mentioned Samanya Lakshana produced in any type of Dhatu and symptoms are only related to the Dhatu concerned.

a) Anaawagadhata ( Wound which is not deep)

b) Talphala Vranata (Fruit of tala tree-blue-black in colour)

c) Susamshita Vrana (Without elevation or depression)

\section{Special symptoms of Samyaka Dagdha} Vrana

a) Shabdapradurbhaw (Production of sound)

b) Durgandhata ( Bad Odour)

c) Twak Sankocha ( Contraction of the skin) 


\section{Electro-Thermal Cautery(13):}

The basic principle is to deliver high frequency current to the human body by means of active electrode and this after passing through the tissue to be diathermied returns via a return electrode. The intense heat produced by the passage of current destroys it in different ways depending on the type of current used, cutting current is undamped and produce cutting effect secondary to intense heat generation within the tissue. It is haemostatic and no bleeding can occur. Coagulating current is highly damped and coagulates by tissue dehydration (water evaporation); its effect is mainly haemostatic. Blending current is a combination of two types of waves introducing both cutting and coagulating effects. Most new surgical units deliver low voltage cutting or blended current from a solid state, generating unit through an isolated bipolar system, which is considered the safest.

Electro cauterization is the process of destroying tissue using heat conduction from a metal probe heated by electric current. The procedure is used to stop bleeding from small vessels (larger vessels being ligated) or for cutting through soft tissue.

This is an apparatus for surgical dissection and hemostasis, using heat generated by a high-voltage, highfrequency alternating current passed through an electrode.

Electro-thermal cautery is one of the invention in the field of surgery in recent year which save times in surgical procedure \& achieve better haemostasis.

\section{Advantages of Electro-thermal cautery}

1) Minimise time of surgery
2) Easily stop bleeding from vessels during surgery

\section{MATERIALS AND METHODS Examination of Patients}

Each patient was thoroughly examined by detailed Proforma designed for the present study on Sentinel Piles. Patients were examined under the following headings.

\section{Examination}

- Inspection

- Palpation

- Per rectal digital examination

- Proctoscopy

\section{History of the Patients}

Complete history of the patient with presenting complaints like protrusion of mass per rectum, discharge, pain, its duration and bowel habit was noted.

History of associated disease like tuberculosis, diabetes mellitus, cardiac disease, malignancy, chronic renal failure etc. was tried to trace out to exclude the condition from the present study.

History of a previous treatment particularly previous surgery, no. of operations, type of operative and also family history, occupation, personal history were taken into consideration to relation to the occupation, recurrence of the disease and habit etc.

\section{Systemic Examination}

Each patient was examined systemically under different systems like digestive, cardio-vascular, respiratory and genitourinary. If any system was found abnormal, then specific investigations were used to confirm inclusion or exclusion criteria.

\section{a) Local Examination}

It was done under following headings with prior consent from patient. Firstly, patient was instructed to lie down in lithotomy position. After this detail examination of perianal region was carried 
out and positive findings were noted down on the case paper.

\section{b) Palpation}

The palpation of the perianal region or the pile mass was done to determine the tenderness in perineal area.

\section{c) Per rectal digital examination}

It was carried out with well lubricated gloved finger and the severity of spasm of sphincter muscle, character of pile mass, hypertrophied papilla, thickened fissure edges, any other growth etc. were examined and documented on paper. Lignocaine gelly were applied in anal canal before $\mathrm{P} / \mathrm{R}$ examination.

\section{d) Proctoscopy}

It was carried out with well lubricated Proctoscope and internal haemorrhoids, chrohn's disease, proctitis, character of pile mass, hypertrophied papilla, thickened fissure edges etc. were examined and documented on paper. Lignocaine gelly were applied in anal canal before Proctoscopy.

\section{Investigations}

$>$ Haemogram

$>$ Venereal Disease Research Labortory

$>$ Australian antigen

$>$ Tri-dot

$>$ Blood sugar level-Random

$>$ Renal Function Test

$>$ Routine urine \& Microscopic

$>$ Electrocardiogram

\section{Consent}

Written consent was taken from patients before including in study for anaesthesia operative procedures, various time to time investigations and examining procedures like digital examination and Proctoscopy.

\section{Number of patients}

60 patients fulfilling the criteria for the diagnosis of disease were registered for the present study irrespective of their age, sex, religion etc.
The patients were selected from the O.P.D. of Dept. of Shalya-tantra, S.V.N.H.T. Ayurved college Rahuri, Ahmednagar, Maharaashtra of our Hospital.

\section{Selection Criteria}

\section{Inclusive criteria}

1. Patients presenting with causes, clinical features and etiopathogenesis of sentinel piles.

2. Patients between the age $16-70$ yrs.

3. Diagnosis done with local examination i.e.

Inspection

Palpation

Per rectal digital examination

Proctoscopy.

4. Physically fit for all surgical/ parasurgical procedures and anaesthesia.

5. Uncomplicated sentinel piles.

6. Indication of Ksharsutra and electro-thermal cautery as stated in literature.

7. Patient presenting with chronic fissure triad

(Sentinel Piles at the base of anal fissure, thickened edges of fissure, Hypertrophied papilla at the apex of fissure.)

\section{Exclusive criteria}

1. Patients below 16 yrs and above 70 yrs of age.

2. Patients with internal and external piles, perianal \& perineal abscess and fistula

3. Rectal prolapsed

4. Crohn's disease

5. Ulcerative colitis

6. Syphilis

7. Condyloma

8. Anal epithelioma

9. HIV Anal Syndrome.

10. Ca rectum

11. Medico-physically unfit patient. 


\section{Methods}

Both procedures will be carried out under Spinal anaesthesia

\section{Group A (Ksharsutra Ligation) Instruments}

Proctoscope, Prepared Ksharsutra, Allies forceps, Artery forceps, Piles Holding Forceps.

Pre-operative

- NBM before 6 hrs.

- Informed written consent.

- Physical fitness.

- Shaving \& preparation of parts.

- Soap water enema 3-4 hrs. prior to procedure.

- Inj. Xylocaine sensitivity test.

- Inj. T. T. $0.5 \mathrm{cc}, \mathrm{IM}$

\section{Operative steps}

- Give spinal anaesthesia by using inj. Lox heavy $5 \%$ to the patient.

- Patient should be in lithotomy position.

- Painting \& draping of the part.

- Lord 's anal dilatation for fissure in ano.

- Tightness of internal sphincter has been made responsible for symptoms .

- Maximal anal dilatation was introduced in an attempt to disrupt these tight bands.

- The whole of the anal canal and lower rectum are slowly and uniformly dilated with the fingers until 4 fingers of both hands are inserted.

- Catch the Sentinel Piles with piles holding forceps.

- With the help of curved cutting needle Ksharsutra was inserted from base of fissure \& brought to the external surface of sentinel piles in the midline then tie it properly.

- Haemostasis achieved.

- Give anal packing with cotton gauze which soaked in Betadine .
Post operative orders

Medicinal Treatment

- Inj. Xone 1 gm , IV , BD (Ceftiaxone) (Alchem Pharma)

For 3 days.

- Inj. Alphacine $500 \mathrm{mg}$, IV , BD (Amikacine) (Ranbaxy Pharma) For 3 Days.

- Inj. Rantin $50 \mathrm{mg}$, IV , BD (Ranitidine) (Indochem Pharma) For 3 days.

- Tab. Emanzen D 1 tab BD (Diclofenac $50 \quad \mathrm{mg}+$ Serratiopeptidase $10 \mathrm{mg}$ ) (USV Pharma ) For 7 days.

- Liq. Duphalac $10 \mathrm{ml}$, HS, (Lactulose) (Abott Pharma) For 7 days.

- IV fluids according to hydration status of the patient.

Non-medicinal Treatment

- NBM for 6 hrs.

- Head low position for $24 \mathrm{hrs}$.

- Sitz bath with luke warm water.

- Temperature,pulse,blood pressure,respiration rate as per need .

\section{Group B ( Electro-thermal Cautery ) Instruments}

Proctoscope, Allies forceps, Artery forceps, Electro-Thermal Cautery machine, Piles Holding Forceps.

\section{Pre-operative}

- NBM before $6 \mathrm{hrs}$

- Informed written consent.

- Physical fitness.

- Shaving \& preparation of parts.

- Soap water enema 3-4 hrs. prior to procedure.

- Inj. Xylocaine sensitivity test.

- Inj. T. T. 0. 5 cc, IM

\section{Operative steps}

- Give spinal anaesthesia by using inj. Lox heavy $5 \%$ to the patient. 
- Patient should be in lithotomy position.

- Painting \& draping of the part.

- Lord' s anal dilatation for fissure in ano.

- Tightness of internal sphincter has been made responsible for symptoms .

- Maximal anal dilatation was introduced in an attempt to disrupt these tight bands.

- The whole of the anal canal and lower rectum are slowly and uniformly dilated with the fingers until 4 fingers of both hands are inserted.

- Catch the Sentinel Piles with piles holding forceps .

- Excise the base of sentinel piles with Electro-Thermal Cautery.

- Haemostasis was achieved.

- Give anal packing of cotton which soaked in Betadine.

\section{Post operative orders}

\section{Medicinal Treatment}

- Inj. Xone 1 gm , IV , BD (Ceftiaxone) (Alchem Pharma)

For 3 days.

- Inj. Alphacine $500 \mathrm{mg}$, IV , BD (Amikacine) (Ranbaxy Pharma) For 3 Days.

- Inj. Rantin $50 \mathrm{mg}$, IV , BD (Ranitidine) (Indochem Pharma) For 3 days.

- Tab. Emanzen D 1 tab BD (Diclofenac $\quad 50 \quad \mathrm{mg}+$ Serratiopeptidase $10 \mathrm{mg}$ ) (USV Pharma) For 7 days.

- Liq. Duphalac 10 ml, HS, (Lactulose) (Abott Pharma) For 7 days.

- IV fluids according to hydration status of the patient.

\section{Non-medicinal Treatment}

- NBM for $6 \mathrm{hrs}$.

- Head low position for $24 \mathrm{hrs}$.

- Sitz bath with luke warm water.
- $\quad \mathrm{TPR} / \mathrm{BP}$ as per need.

Follow up days: $35^{\text {th }}, 45^{\text {th }}$.

$$
3^{\text {rd }}, 5^{\text {th }}, 7^{\text {th }}, 10^{\text {th }}, 15^{\text {th }}, 21^{\text {st }}, 28^{\text {th }} \text {, }
$$

\section{Dietary advice}

The patients were asked to follow the advice regarding Pathya and Apathya.

\section{Clinical assessment}

The changes observed in signs and symptoms were assessed by adopting suitable scoring methods and the objective signs by using appropriate clinical tools.

\section{Observations}

Observations were recorded on case paper and data collected by clinical study. Afterwards it will be represented by graph and statistical tabular forms on the basis of Ayurvedic concept of Arsha.

Table No.1.2 Observation Parameters

\begin{tabular}{|l|l|}
\hline \multicolumn{2}{|l|}{ Rakta Srava (bleeding p/r) } \\
\hline 0 & No bleeding \\
\hline 1 & $\begin{array}{l}\text { Bleeding along with defecation steak } \\
\text { on stool }\end{array}$ \\
\hline 2 & $\begin{array}{l}\text { Drop wise bleeding after defecation } 0 \text { - } \\
10 \text { drops occasional }\end{array}$ \\
\hline 3 & $\begin{array}{l}\text { Drop wise bleeding after defecation 10 } \\
-20 \text { drops }\end{array}$ \\
\hline 4 & Profuse bleeding as splashing toilet pan \\
\hline Guda Kandu (itching) \\
\hline 0 & No itching \\
\hline 1 & $\begin{array}{l}\text { Itching remains } \\
\text { defecation. }\end{array}$ \\
\hline 2 & $\begin{array}{l}\text { Itching remains for } 4 \text { - 5 hrs. after } \\
\text { defecation }\end{array}$ \\
\hline 3 & Itching remains for whole day \\
\hline Guda Pida (cutting pain) \\
\hline 0 & No cutting pain \\
\hline 1 & Relieved in 1 hr. after defecation \\
\hline 2 & Relieved in $2-4$ hrs after defecation, \\
\hline 3 & Relived in 4-7 hrs after defecation \\
\hline 4 & Present whole day \\
\hline
\end{tabular}




\begin{tabular}{|l|l|}
\hline \multicolumn{2}{|l|}{ Guda Daha (burning pain) } \\
\hline 0 & No burning pain \\
\hline 1 & Relieved in 1 hr after defecation \\
\hline 2 & Relieved in 4 -5 hrs. after defecation \\
\hline 3 & Present whole day \\
\hline \multicolumn{2}{|l|}{ Sparshasahatwa (tenderness) } \\
\hline 0 & No tenderness \\
\hline 1 & Tenderness on touch \\
\hline 2 & Tenderness on light pressure \\
\hline 3 & Tenderness on palpation \\
\hline 4 & Patient does not allow palpation due to \\
\hline \multicolumn{2}{|l|}{ pain. } \\
\hline 0 Shotha (inflammation) \\
\hline 0 & No inflammation \\
\hline 1 & Mild redness of ulcer \\
\hline 2 & Redness 1-5 mm around anus \\
\hline 3 & Redness 5-10 mm around anus \\
\hline Guda Srava (mucous discharge) \\
\hline 0 & No mucous discharge \\
\hline 1 & Moist feeling \\
\hline 2 & Changing cloths 1 time a day \\
\hline 3 & Changing cloths 2 times a day \\
\hline 4 & Changing cloths more than 2 times a \\
\hline & day \\
\hline Malavashtambh (constipation) \\
\hline 0 & No constipation \\
\hline 1 & Stool as a dome \\
\hline 2 & Hard stool \\
\hline 3 & Unable to defecate \\
\hline Mamsankur (protrusion of mass) \\
\hline 0 & No mass \\
\hline 1 & $1 / 2$ to 1 cm \\
\hline 2 & 1 to 2 cm \\
\hline 3 & Above 2 cm \\
\hline \multicolumn{2}{|l|}{} \\
\hline
\end{tabular}

Table No. 1.3 Post-operative Symptoms Progress

\section{Irritation}

\begin{tabular}{|l|llll|}
\hline 0 & No Irritation & & & \\
\hline 1 & $\begin{array}{l}\text { Irritation remains for } 1 \\
\text { defecation. }\end{array}$ & hr. after \\
\hline 2 & Irritation remains for $4-5$ & $\mathrm{hrs}$ & after \\
\hline
\end{tabular}

\begin{tabular}{|l|l|}
\hline & defecation . \\
\hline 3 & Irritation remains for whole day. \\
\hline Allergy \\
\hline 0 & Absent \\
\hline 1 & Present \\
\hline Healing of wound \\
\hline 0 & No healing \\
\hline 1 & Healing in 5-7 days. \\
\hline 2 & Healing in 7-15 days. \\
\hline 3 & Healing in 16-21 days. \\
\hline 4 & Healing after 21 days. \\
\hline Fibrosis \\
\hline 0 & Absent \\
\hline 1 & Present \\
\hline Foul smell \\
\hline 0 & Absent \\
\hline 1 & Present \\
\hline Necrosis \\
\hline 0 & No Necrosis \\
\hline 1 & Necrosis at the time of surgery. \\
\hline 2 & Necrosis 7-10 days after surgery. \\
\hline 3 & Necrosis 11-15 days. \\
\hline 4 & Necrosis after 15 days. \\
\hline
\end{tabular}

Criteria for assessment of overall symptoms

Percentage of relief in symptoms and sign with respect to each of the patient is as followed and will be classified as per the definitions of cured, markedly improved, improved and unchanged.

1. Cured Total relief in symptoms $75 \%$ to $100 \%$

2. Markedly improved $50 \%$ to $75 \%$ improvement from signs and symptoms is termed as markedly improved.

3. Improved Improvement range in between $25 \%$ to $50 \%$ responded by patient in signs and symptoms is taken for improved.

4. Unchanged The patients presenting less than $25 \%$ improvement in their signs and symptoms are taken as unchanged. 


\section{RESULT}

Table No 1.4 Effect of Therapy on Cardinal Symptoms of Sentinel Piles of gr-A

\begin{tabular}{|l|l|l|l|l|l|l|l|l|l|}
\hline $\begin{array}{l}\text { Cardinal } \\
\text { Symptoms }\end{array}$ & N & $\begin{array}{l}\text { Mean } \\
\text { B.T. }\end{array}$ & $\begin{array}{l}\text { Mean } \\
\text { A.T. }\end{array}$ & SD & SE & t cal & $\begin{array}{l}\mathbf{p} \text { value } \\
\text { at } \\
\mathbf{0 . 0 0 1 \%}\end{array}$ & Result & $\begin{array}{l}\text { \% Of } \\
\text { Relief }\end{array}$ \\
\hline Gudapida & 30 & 3.3 & 0.43 & 0.73 & 0.13 & 22 & $\mathrm{P}<0.001$ & H.S & 98.86 \\
\hline Gudadaha & 30 & 2.9 & 0.33 & 0.28 & 0.051 & 50.19 & $\mathrm{P}<0.001$ & H.S & 88.50 \\
\hline Rakta srava & 13 & 2 & 0.15 & 0.37 & 0.10 & 18.4 & $\mathrm{P}<0.001$ & H.S & 92.30 \\
\hline Guda Kandu & 17 & 2 & 0.11 & 0.69 & 0.167 & 11.25 & $\mathrm{P}<0.001$ & H.S & 94.11 \\
\hline SpArshasahatwa & 26 & 2.96 & 0.38 & 0.57 & 0.11 & 23.72 & $\mathrm{P}<0.001$ & H.S & 87.01 \\
\hline Shotha & 12 & 2 & 0.16 & 0.38 & 0.10 & 18.3 & $\mathrm{P}<0.001$ & H.S & 91.66 \\
\hline GudaStrava & 11 & 1 & 0.090 & 0.30 & 0.09 & 10 & $\mathrm{P}<0.001$ & H.S & 90.90 \\
\hline Malavasthmbha & 29 & 2.31 & 0.10 & 0.74 & 0.13 & 16.61 & $\mathrm{P}<0.001$ & H.S & 95.52 \\
\hline Mansanankur & 30 & 1.3 & 0.06 & 0.53 & 0.09 & 14.44 & $\mathrm{P}<0.001$ & H.S & 94.87 \\
& & & & & & & & & \\
\hline
\end{tabular}

Table No 1.5 Effect of Therapy on Cardinal Symptoms of Sentinel Piles of gr-B

\begin{tabular}{|l|l|l|l|l|l|l|l|l|l|}
\hline $\begin{array}{l}\text { Cardinal } \\
\text { Symptoms }\end{array}$ & N & $\begin{array}{l}\text { Mean } \\
\text { B.T. }\end{array}$ & $\begin{array}{l}\text { Mean } \\
\text { A.T. }\end{array}$ & SD & SE & t cal & $\begin{array}{l}\mathbf{p} \text { value } \\
\text { at } \\
\mathbf{0 . 0 0 1 \%}\end{array}$ & Result & $\begin{array}{l}\text { \% Of } \\
\text { Relief }\end{array}$ \\
\hline Gudapida & 30 & 3.13 & 0.86 & 0.73 & 0.13 & 22 & $\mathrm{P}<0.001$ & H.S & 72 \\
\hline Gudadaha & 30 & 2.83 & $\mathrm{O} .7$ & 0.68 & 0.12 & 17.75 & $\mathrm{P}<0.001$ & H.S & 75.29 \\
\hline Rakta srava & 16 & 1.62 & 0.5 & 0.71 & 0.17 & 6.58 & $\mathrm{P}<0.001$ & H.S & 69 \\
\hline Guda Kandu & 11 & 1.90 & 0.18 & 0.33 & 0.9 & 12.11 & $\mathrm{P}<0.001$ & H.S & 90.47 \\
\hline SpArshasahatwa & 12 & 3 & 0.58 & 1.24 & 0.35 & 7.37 & $\mathrm{P}<0.001$ & H.S & 80 \\
\hline Shotha & 10 & 2.1 & 0.1 & 0.46 & 0.14 & 14.28 & $\mathrm{P}<0.001$ & H.S & 95.23 \\
\hline Gudastrava & 10 & 1 & 0.3 & 0.34 & 0.10 & 11 & $\mathrm{P}<0.001$ & H.S & 70 \\
\hline Malavasthmbha & 30 & 2.43 & 0.43 & 0.64 & 0.11 & 18.18 & $\mathrm{P}<0.001$ & H.S & 82.19 \\
\hline Mansanankur & 30 & 1.46 & 0.06 & 0.55 & 0.10 & 14 & $\mathrm{P}<0.001$ & H.S & 95.45 \\
\hline
\end{tabular}

Table No 1.6 Overall effect of Therapy Gr-A

\begin{tabular}{|l|l|l|}
\hline Effect & No of Pt & Percentage \\
\hline Cured & 25 & $83.33 \%$ \\
\hline Markedly Improved & 04 & $13.33 \%$ \\
\hline Improved & 01 & $3.33 \%$ \\
\hline Unchanged & - & - \\
\hline
\end{tabular}

Table No 1.7 Overall effect of Therapy Gr-B

\begin{tabular}{|l|l|l|}
\hline Effect & No. of Pts. & Percentage \\
\hline Cured & 18 & $60 \%$ \\
\hline Markedly Improved & 10 & $33.33 \%$ \\
\hline Improved & 02 & $6.66 \%$ \\
\hline Unchanged & - & - \\
\hline
\end{tabular}

Table No 1.8 Post Operative Symptoms Progress Chart Gr-A

\begin{tabular}{|l|l|l|l|}
\hline Symptoms & Grading & No of patients & Percentage \\
\hline Irritation & Irritation remains for $1 \mathrm{hr}$ after defecation & & \\
\hline
\end{tabular}




\begin{tabular}{|l|l|c|c|}
\hline & & 4 & $13.33 \%$ \\
\hline & Irritation remains for 4-5 hrs after defecation & 26 & $86.66 \%$ \\
\hline Allergy & Present & 12 & $40.00 \%$ \\
\hline & Absent & 18 & $60.00 \%$ \\
\hline $\begin{array}{l}\text { Healing of } \\
\text { wound }\end{array}$ & Healing in 7-15 days & 18 & $60.00 \%$ \\
\hline & Healing after 21 days & 12 & $40.00 \%$ \\
\hline Fibrosis & Present & 2 & $06.66 \%$ \\
\hline & Absent & 28 & $93.33 \%$ \\
\hline Faull smell & Present & 13 & $43.34 \%$ \\
\hline & Absent & 17 & $56.66 \%$ \\
\hline Necrosis & Necrosis in 7-10 days after surgery & 19 & $63.33 \%$ \\
\hline & Necrosis in 11-15 days after surgery & $36.66 \%$ \\
\hline
\end{tabular}

Table No 1.9 Post Operative Symptoms Progress Chart Gr-B

\begin{tabular}{|l|l|c|c|}
\hline Symptoms & Grading & No of patients & Percentage \\
\hline Irritation & Absent & 12 & $40.00 \%$ \\
\hline & $\begin{array}{l}\text { Irritation remains for 1 hr } \\
\text { after defecation }\end{array}$ & 8 & $26.66 \%$ \\
\hline & $\begin{array}{l}\text { Irritation remains for 4-5 hrs } \\
\text { after defecation }\end{array}$ & 10 & $33.33 \%$ \\
\hline Allergy & Present & 00 & $00.00 \%$ \\
\hline & Absent & 30 & $100.00 \%$ \\
\hline $\begin{array}{l}\text { Healing } \\
\text { wound }\end{array}$ & Healing in 7-15 days & 14 & $46.66 \%$ \\
\hline & Healing in 16-21 days & 8 & $26.66 \%$ \\
\hline Fibrosis & Healing after 21 days & 8 & $26.66 \%$ \\
\hline & Present & 24 & $80.00 \%$ \\
\hline Faull smell & Absent & 6 & $20.00 \%$ \\
\hline & Present & 29 & $96.33 \%$ \\
\hline Necrosis & Absent & 30 & $100.00 \%$ \\
\hline
\end{tabular}

\section{Conclusion}

- Sentinel Piles is one of the clinical feature of chronic fissure triad.

- Incidence of Sentinel piles is more in young age than old age.

- More chances of Sentinel Piles at anterior site in female and posterior site in male.

- Lord's anal dilatation necessary for fissure in ano before both therapy of Sentinel Piles to break the pathology.

- Effect of Ksharsutra Ligation on Sentinel Piles is better than Electro-Thermal Cautery on cardinal symptoms of Sentinel Piles.

- Irritation present after Ksharsutra Ligation which is absent in ElectroThermal Cautery. 
- Healing of wound early in Ksharsutra Ligation than ElectroThermal Cautery.

- Chances of fibrosis of wound are more in Electro-Thermal Cautery than Ksharsutra Ligation.

- Faull smell present in some patient after Ksharsutra Ligation.

- Sentinel Piles mass cut off at the time of surgery in Electro-Thermal Cautery while in Ksharsutra Ligation it necrose after 7-15 days.

- It can be concluded that the Ksharsutra Ligation is the ideal modalities for management of Sentinel Piles even than modern surgical treatment.

- Excellence of Ksharsutra Ligation over other surgical procedure

- Minimum trauma.

- Minimum tissue loss.

- Minimum bleeding.

- Minimum hospital stay (one day care procedure).

- Ksharsutra cut and heals from the base.

- No incontinence because sphincter destruction is minimum.

- Therapy cost is less.

- Very narrow \& fine scar.

- No anal stricture.

\section{References}

1. John Goligher, Surgery Of the Anus Rectum And Colon. AIBTS Publisher's \& Distributers,London, $5^{\text {th }}$ Edition,2002,P-100.

2. Somen Das, A Concise text book of Surgery, S. Das Publications, Calcutta, $4^{\text {th }}$ Edition, 2005, P-1061.

3. Maingot's, Abdominal Operations,part-2, Library Of Congress Publication, $11^{\text {th }}$ Edition, 2007, P-680.
4. Pt.Kashinatha shastri, Charaka Samhita part- 2, Chokhamba Bharati Acadamy, Varanasi, $4^{\text {th }}$ Edition, 2001,P$1027,1028$.

5. Pt. Hemaraj Sharma, Kashyapa Samhita, Chokhamba Sanskrit Sansthan, Varanasi, $1^{\text {st }}$ Edition, 1993, P-299.

6. Anantkumar Shekokar, Shalya Tantra 2 , Shantanu Prakashan, Ahmednagar, $1^{\text {st }}$ Edition, 2007, P-307

7. Sriram bhat M., SRB's manual of surgery, jaypee brothers medical publishers Ltd. New Delhi $3^{\text {rd }}$ edition 2009 p-911

8. Anantram Sharma, Sushruta Samhita Part-2, Chokhamba Surbharati Prakashan, Varanasi, $1^{\text {st }}$ Edition, 2004, P-225.

9. K.rajgopal shenoy., Manipal manual of surgery, CBS publishers and distributors New Delhi $2^{\text {nd }}$ edition 2005 p-532

10. Somen Das, A practice Guide to Operative Surgery, S. Das Publications, Calcutta, $4^{\text {th }}$ Edition, 1996, P-410.

11. Sharma K.R. \& Dr. Kulwant Singh,Kshar-Sutra Therapy In Fistula In Ano And OtherAno-Rectal Disorders,Rastriya Ayurved Vidyapeeth Publication, New Delhi, $1^{\text {st }}$ Edition,1994 ,P-43-59.

12. Anantram Sharma, Sushruta Samhita Part-1, Chokhamba Surbharati Prakashan, Varanasi, $1^{\text {st }}$ Edition, 2004, P- 86.

13. Anantkumar Shekokar, Principle And Practices Of Agnikarma, Shantanu Prakashan, Ahmednagar, $1^{\text {st }}$ Edition,2007, P-20. 